\title{
Energy management as an innovative practice of public administration in the Leningrad Region
}

\author{
Nadeshda Kosmacheva ${ }^{1,{ }^{*}}$, Galina Cherkasskaya ${ }^{2}$, and Irina Dolgova ${ }^{3}$ \\ ${ }^{1}$ Pushkin Leningrad State University, 10 Petersburg Highway, 196605 St. Petersburg, Russian Federation \\ ${ }^{2}$ Pushkin Leningrad State University, 10 Petersburg Highway, 196605 St. Petersburg, Russian Federation \\ ${ }^{3}$ Bauman Moscow State Technical University, 5, 2-ya Baumanskaya, 105005 Moscow, Russian Federation
}

\begin{abstract}
The purpose of the research is to identify vector of sustainable industrial development in the context of limited resources, in particular, in the context of the efficient energy use as a decisive factor. An attempt has been made to determine the level of managerial and economic efficiency of energy sector management in the Leningrad Region of the Russian Federation through the introduction of energy management methods and measures. The energy sector economy basics and peculiarities have been considered in the course, including goal setting, planning and execution of energy management activities in the Leningrad region at the state, municipalities and corporations level. A certain readiness of the main state municipal and corporate levels management institutions to implement some energy management areas, methods and activities of the world standard aimed at achieving efficiency indicators set by the planning and legal documents of higher organizations, is set up. At the same time, the executive and consumer levels of activity demonstrate a certain lack of energy management importance understanding as a strategy and set of rules conduct in production and in everyday life. The level of management and economic efficiency of the energy sector management in the Leningrad Region has been determined as an average. And it was concluded on the basis of the conducted research that it is necessary to introduce a systematic approach to the solution of strategic issues of region sustainable development into management practice of the Leningrad Region, as well as to ensure a closer connection between energy, socio-economic and environmental projects.
\end{abstract}

\section{Introduction}

In the conditions of population growth and depletion of energy sources, the tasks of ensuring sustainable social and economic development of the territories cannot be solved by the regional system of power without the use of innovative solutions in the field of energy management in the energy sector.

Increasing the energy sources management, resources and consumption efficiency becomes one of the main trends in the theory and practice of public and corporate governance of socio-economic systems of various types and levels.

According to the World Bank's known data (for 2009), the implementation of the existing energy saving potential at that time would have allowed Russia to save up to 100-150 bil. RUB of federal and municipal budgets per year (25-40\% of GDP (in 2009 prices) ) [1].

However, it is important that the declared and/or implemented energy saving and energy procurement management policy in the regions themselves are consistent with the task of ensuring sustainable development of the territories and improving the life quality of the population.

However, the studies are pointing to certain problems in this area, both at the level of planning and the level of implementation of planned activities $[2,3]$.
Due to the significant differences in the location of administratively designated areas in the Russian Federation, their geographical and climatic characteristics, the location of productive forces, including production and distribution of energy, the research of local practice of applying strategic guidelines in the economics field of the energy sector and energy management at the level of specific regions are of scientific and practical interest.

The purpose of this article (research) is to determine the level of managerial and economic efficiency of energy sector management in the Leningrad region of the Russian Federation through the introduction of energy management methods and measures.

\section{Materials and methods}

The scientific and informational materials on the energy sector economics, theory and practice of energy management, including information about the work of the energy sector, corporations, state and municipal authorities and management of the Leningrad region of the Russian Federation, as well as documents of the legal framework of energy management of the Russian Federation and the UN, are used in the paper.

The modern methodology of socio-economic research, including system and process approaches,

*Corresponding author: n.kosmacheva@lengu.ru 
methods of forecasting, comparison, formal-logical and statistical analysis, as well as tools of scientific analysis of documents and results of activities, are used in the paper.

\section{The result}

As is known, the Leningrad Region (a constituent entity of the Russian Federation, with 94.6 thousand square kilometers total area) is a highly urbanized territory. 19 cities of the region and 10 cities of district subordination are home to almost two-thirds of its population, and eight cities of the region (Vyborg, Gatchina, Tikhvin, Sosnovy Bor, Kirishi, Vsevolozhsk, Sertolovo, Murino) belong to the average category, in which the number of residents is over 50 thousand people.

As of the $1^{\text {st }}$ of January, 2020, the Leningrad Region population was 1875.9 thousand people, including 615.6 thousand people in a rural areas.

In general, the region has an imbalance in the settlement system, uneven development of municipalities and sometimes an increase in depreciation of fixed assets of the municipal infrastructure.

In total, there are 205 municipal entities on the territory of the Oblast, but the highest public authorities of the Leningrad Oblast are currently located in St. Petersburg.

The region has a vast territory $(500 \mathrm{~km}$ from west to east and $320 \mathrm{~km}$ from north to south), an external (state) border with two countries: Finland and Estonia, and an internal border with 5 subjects of the Russian Federation: the Republic of Karelia and regions: Vologda oblast, Novgorod oblast and Pskov oblast, as well as the federal city of St. Petersburg.

The Leningrad Region is one of the leaders in economic development in the North-Western Federal District of the Russian Federation.

The region's economy is based on industry, accounting for about a third of the GRP structure.

The following industries are represented in the industrial complex of the Leningrad Region: mechanical engineering, automotive industry, shipbuilding, chemical production, petrochemistry, timber processing, pulp and paper production, aluminum industry, construction materials industry, etc.

The key companies located in the Leningrad Region are Philip Morris Izhora CJSC, Novatek-Ust-Luga LLC, Kirishinefteorgsintez Production Association LLC, Tikhvin Freight Car Building Plant JSC and others [4].

The Program of the region development until 2030 provides the implementation of several large investment projects in the sphere of petrochemical, transport and energy industry $[5,6]$.

The main indicators of the regional economy, including the energy sector of the Leningrad Region, are presented in Table 1 .
Table 1. Leningrad Region economy and energy sector key indicators.

\begin{tabular}{|c|c|c|c|c|}
\hline Indicator & $\mathbf{2 0 1 3}$ & $\mathbf{2 0 1 5}$ & $\mathbf{2 0 1 7}$ & $\mathbf{2 0 1 9}$ \\
\hline $\begin{array}{c}\text { Gross Regional } \\
\text { Product in the } \\
\text { basic.prices, bil. } \\
\text { RUB/bil. EUR }\end{array}$ & 16.1 & 12.2 & 13.8 & 12.9 \\
\hline $\begin{array}{c}\text { - per capita, } \\
\text { thous. RUB }\end{array}$ & 386.2 & 480.3 & 534.6 & 610.0 \\
\hline $\begin{array}{c}\text { Electricity } \\
\text { consumption, } \\
\text { bil. kWh }\end{array}$ & 18.951 & 19.167 & 25.16 & 21.500 \\
\hline $\begin{array}{c}\text { Maximum } \\
\text { power } \\
\text { consumption, } \\
\text { MW }\end{array}$ & 3129 & 2995 & 4511 & 7703 \\
\hline $\begin{array}{c}\text { Balanced } \\
\text { financial result } \\
\text { (profit minus } \\
\text { loss) in the } \\
\text { economy, bil. } \\
\text { RUB }\end{array}$ & 96.0 & 109.6 & 161.9 & 144.2 \\
\hline $\begin{array}{c}\text { Investments in } \\
\text { the fixed assets, } \\
\text { bil. RUB } \\
\text { index } \\
\text { year previous } \\
\text { \%ecember), }\end{array}$ & 253.6 & 225.9 & 337.7 & 419.1 \\
\hline $\begin{array}{c}\text { Consumer price } \\
\text { (D) }\end{array}$ & 106.0 & 113.3 & 102.7 & 102.9 \\
\hline
\end{tabular}

*Reference: EURO exchange rate for the 2013 - 2019 years (43 rub.; 70 rub.; 70 rub.)

The figures for 2019 are estimates.

Source: authors' calculations based on [5-7] and statistical data http://petrostat.gks.ru

The Leningrad Region produces about $4 \%$ of electricity and $7 \%$ of oil products from total Russian volumes.

At the same time, according to the data of the special GIS "Energy Efficiency" (expert portal on energy saving issues https://gisee.ru/regionsupport/), the energy consumption in the region was 7569157 toe in 2018, and the energy intensity was 214,30 , which is lower than the average level. The fuel and energy balance of the Leningrad Region is represented by six types of primary resources (shale, peat, electricity, crude oil, natural gas and coal). The last three of these are imported into the region, and the first three are produced. Coal is imported from the Kuznetsk and Pechora coal basins, natural gas is supplied from the Komi Republic and northern regions of the Tyumen Region, and refineries from the cities of Kirishi, Ufa, Perm and Yaroslavl are the main suppliers of fuel oil. Thus, the supply of all natural gas and coal required to meet the regional energy generation needs, 
primarily thermal power, is carried out through imported procedures, while almost entire volume of oil products produced by "Kirishinefteorgsintez" is sent outside the region and outside the Russian Federation.

Electricity supply to consumers located in the Leningrad Region is carried out by an integrated power system (Saint-Petersburg and the Leningrad Region). It, being the largest, is a part of the United Power System of the North-West (IES of the North-West), along with the power systems of the Murmansk, Novgorod, Pskov Regions, Arkhangelsk and Kaliningrad Regions (since 2004) and the Nenets Autonomous District, as well as the power system of the Republic of Karelia and the Republic of Komi. At present, more than a dozen of power generating and distribution companies work in the Leningrad Region, including TGC-1 PJSC, Rosenergoatom Concern JSC, Rosseti Lenenergo PJSC, various CHP, and industrial power plants.

Leningrad NPP generates the main proportion of electricity in the region. The LNPP is developing progressively (work in the second power unit is being completed), so the Leningrad Region is a major supplier of electricity to the country's unified energy system, supplying not only St. Petersburg and the entire NorthWest, but also to the EU countries, primarily Finland. The structure of electricity consumption in the region is stable: half of it is consumed by the primary sector; about a tenth is a domestic consumption. The rest is distributed between the secondary and tertiary sectors, including industry and transport. The fuel and energy resources conversion sector remains of key importance in the use of the gross mass of primary energy and its equivalents, as the main consumers of fuel and energy resources of the Leningrad Region are the oil refining industry and energy production. In general, the balance of the electric power industry is steadily positive and has available excess capacity.

As it can be seen, the energy sector plays an important role in the economy of the Leningrad Region. The efficiency of economy and management in this sector largely determines the final efficiency of public administration in the region.

In order to improve the economic and managerial efficiency of the energy sector, the Oblast Government applies, using the regulatory framework and experience of the federal [8,9] and world-class [10], methods and measures of energy management [11], implementing them at the state, municipal and corporate levels of public production and management, taking into account environmental problems [12].

The set of methods and measures of energy management can include demand management, energy consumption and load [13], and supply, as well as procurement management, energy production and energy consumption management, carried out at the state, municipal, corporate and individual levels.

According to the region data, this activity has some success [14]; and, moreover, the rating of the Leningrad Region at the country level is 28 (2015) and 5 (2016 2019). The results of management activities of municipalities' energy efficiency for 2016-2019 are determined by a special rating and selectively presented in Table 2.

Table 2. The results of municipalities' energy efficiency management activities for 2016-2019.

\begin{tabular}{|c|c|c|c|c|}
\hline Region & $\begin{array}{c}\text { Population } \\
\text { for 2020 }\end{array}$ & $\begin{array}{c}\text { Munici } \\
\text { pal } \\
\text { area } \\
\text { rating } \\
\text { based } \\
\text { on } \\
\mathbf{2 0 1 5} \\
\text { data }\end{array}$ & $\begin{array}{c}\text { Munici } \\
\text { pal } \\
\text { area } \\
\text { rating } \\
\text { based } \\
\text { on } \\
\mathbf{2 0 1 7} \\
\text { data }\end{array}$ & $\begin{array}{c}\text { Munici } \\
\text { pal } \\
\text { area } \\
\text { rating } \\
\text { based } \\
\text { on } \\
\mathbf{2 0 1 9} \\
\text { data }\end{array}$ \\
\hline $\begin{array}{c}\text { Leningrad } \\
\text { region, total }\end{array}$ & 1875.9 & & & \\
\cline { 1 - 2 } $\begin{array}{c}\text { including the } \\
\text { municipal } \\
\text { neighborhoods: }\end{array}$ & & & & \\
\hline Boxitogorsky & 48.6 & 7 & 16 & 12 \\
\hline Volosovsky & 51.8 & 14 & 18 & 14 \\
\hline Volkhovsky & 88.2 & 6 & 10 & 3 \\
\hline Vsevolozhsky & 438.6 & 9 & 9 & 13 \\
\hline Vyborgsky & 198.2 & 13 & 17 & 9 \\
\hline Gatchinsky & 238.6 & 9 & 12 & 10 \\
\hline Kingiseppsky & 74.9 & 16 & 11 & 5 \\
\hline Kirishsky & 61.5 & 1 & 1 & 6 \\
\hline Kirovsky & 106.0 & 12 & 4 & 7 \\
\hline Lodeynopolsky & 28.0 & 10 & 5 & 1 \\
\hline Lomonosovsky & 76.8 & 11 & 15 & 13 \\
\hline Luzhsky & 70.8 & 3 & 3 & 4 \\
\hline Podporozhsky & 27.7 & 9 & 8 & 8 \\
\hline Priozersky & 60.4 & 2 & 2 & 7 \\
\hline Slantsevsky & 42.3 & 5 & 14 & 3 \\
\hline Tikhvinsky & 69.5 & 2 & 6 & 1 \\
\hline Tusnensky & 126.9 & 8 & 13 & 2 \\
\hline $\begin{array}{c}\text { urban district } \\
\text { Sosnovoborsky }\end{array}$ & 67.7 & 4 & 7 & 11 \\
\cline { 1 - 2 } & & & & \\
\hline
\end{tabular}

The rating of energy efficiency of the MD is determined by 13 criteria in accordance with the value of the consolidated energy efficiency index calculated for each MD (UD) of the LR based on the maximum number of points -115 . The main sources of information for the indicators of energy efficiency of LR MD (UD) ranking were the information systems (GIS "Energy Efficiency" module, GIS "Energy Efficiency", RGIS "Energy Efficiency"). These include the official information prepared by the administrations of LR MD (UD) within the framework of the information preparation on the Leningrad Region for inclusion to the state report on the state of energy saving and energy efficiency in the Russian Federation $[15,16]$. As it can be seen, there is a multidirectional dynamics of the rating, but a long-term high rating of the Kirishi MD as a consequence or a reflection of the conscious corporate energy efficiency of the enterprises located in it, is observed. Conversely, there is also a consistently low rating of Volosovsky $\mathrm{MOE}$ as a consequence of the negative individual and entrepreneurial consumer behavior in its energy sector.

One of the important areas of energy management reflected in this rating is the availability of metering devices for all used energy resources, for both general and individual use. The equipping level with energy metering devices in the Leningrad Region in 2016 - 2019 is presented in Tables 3 and 4. 
Table 3. Level of equipment with household energy metering devices in the Leningrad Region in 2016 - 2019.

\begin{tabular}{|c|c|c|c|c|}
\hline \multirow{2}{*}{$\begin{array}{c}\text { Type of energy } \\
\text { resource }\end{array}$} & \multicolumn{4}{|c|}{$\begin{array}{c}\text { Household metering devices } \\
\text { \% of equipment in }\end{array}$} \\
\cline { 2 - 5 } & $\mathbf{2 0 1 6}$ & $\mathbf{2 0 1 7}$ & $\mathbf{2 0 1 8}$ & $\mathbf{2 0 1 9}$ \\
\hline Cold water supply & 38.84 & 44.90 & 47.30 & 50.42 \\
\hline Hot water supply & 31.08 & 36.86 & 43.34 & 46.98 \\
\hline Thermal power & 36.59 & 35.18 & 40.41 & 44.61 \\
\hline $\begin{array}{c}\text { Electrical energy } \\
\text { (without public } \\
\text { area meters) }\end{array}$ & 34.96 & 37.87 & 43.12 & 44.95 \\
\hline Gas & 5.34 & 4.78 & 6.95 & 9.96 \\
\hline
\end{tabular}

Table 4. Level of equipment with individual energy metering devices in the Leningrad Region in 2016 - 2019.

\begin{tabular}{|c|c|c|c|c|}
\hline \multirow{2}{*}{$\begin{array}{c}\text { Type of energy } \\
\text { resource }\end{array}$} & \multicolumn{4}{|c|}{$\begin{array}{c}\text { Individual metering devices } \\
\text { \% of equipment in }\end{array}$} \\
\cline { 2 - 5 } & $\mathbf{2 0 1 6}$ & $\mathbf{2 0 1 7}$ & $\mathbf{2 0 1 8}$ & $\mathbf{2 0 1 9}$ \\
\hline Cold water supply & 72.42 & 74.24 & 77.96 & 84.54 \\
\hline Hot water supply & 74.55 & 79.58 & 82.71 & 86.20 \\
\hline Thermal power & 5.06 & 4.13 & 22.29 & 38.19 \\
\hline $\begin{array}{c}\text { Electrical energy } \\
\text { (without public } \\
\text { area meters) }\end{array}$ & 89.90 & 97.68 & 98.63 & 99.22 \\
\hline Gas & 45.74 & 44.18 & 48.16 & 47.10 \\
\hline
\end{tabular}

As it can be seen, the energy metering devices equipping level in the Leningrad Region is not sufficient, moreover, its dynamics for 2016-2019 is multidirectional, which indicates a certain problematicity of standard energy management measures implementation at the individual consumption level.

Indicators of equipment with energy meters in the Leningrad Region of buildings, structures, and structures of municipal property occupied by administrations of MD (UD) of the LR and settlements of MD of the LR, MI of the LR for municipal entities are ranging from $71 \%$ to $100 \%$.

It should be noted that since 2003, the region has been implementing the 'Concept of Fuel and Energy Resources Development for Municipal Boilerhouses of the Leningrad Region until 2020'. It has been aimed at optimizing the fuel balance structure by means of more local fuels, gasification of heat supply facilities, reduction of fuel oil and coal consumption, and general improvement of fuel efficiency at municipal boilers of the Leningrad Region. So far, the concept is being implemented in a sluggish manner, as the Leningrad Region Government is only looking for huge investors to convert boiler houses to local fuels and to introduce mini-CHPs for combined heat and power generation in the Leningrad Region's communities. At the same time, existing players in the energy sector are successfully implementing their own investment programs. For example, in 2015, LOESK invested over 2.5 billion RUB in the Leningrad Region's power grid sector, and about 3.3 billion RUB in 2016. In 2017, LOESK's specialists connected about 2.5 thousand subscribers to the network with a total capacity of about $100 \mathrm{MW}$. Experts believe that the number of technical connections and the volume of capacity allocated by the company will grow year by year [3]. In general, energy efficiency improvements are implemented by the Government at the oblast and municipal levels, with a breakdown by sectors (energy, housing and public utilities, agriculture, transport, public sector), with the involvement of budgetary and extrabudgetary funds. Within the framework of the subprogram "Energy Saving and Energy Efficiency in the Leningrad Region" of the Leningrad Region state program "Ensuring the sustainable functioning and development of municipal and engineering infrastructure and energy efficiency of the Leningrad Region", a set of measures is implemented in the heat and water supply systems, in the housing stock of the region (500 million rubles annual financing).

In general, the measures, planned and undertaken by the Leningrad Region Government in 2018-2019, to improve the regional policy in the energy saving and energy efficiency field may include measures to increase the responsibility of Leningrad Region sectoral executive authorities for the implementation of energy saving and energy efficiency policies in the sectors of the Leningrad Region economy. This also includes recommendations to the Leningrad Region municipalities to adjust the municipal programs in the energy saving and energy efficiency field, including the activities of the "road maps" of the municipal districts (urban district) for the installation of energy metering devices and automated individual heat supply points with weather and hourly regulation, as well as the modernization of internal lighting systems in Leningrad Region municipal institutions. This aims to provide funds from the local budget for their realization and other equally significant events.

Thus, the study allowed one to determine the management level and economic efficiency of the energy sector management in the Leningrad Region as an average. It showed a certain readiness of the main management institutions at the state, municipal and corporate levels to implement some areas, methods and activities of energy management of the world standard, aimed at the achievement of performance indicators set by the planning and title documents of higher organizations. The executive and consumer levels of activity demonstrate a certain lack of understanding the of energy management importance as a strategy and a set of rules conduct in production and everyday life.

\section{Discussion}

It should be noted that although the energy sector economics is a rather topical area of scientific research in recent years, the problems of energy management from 2008 to the present time in our opinion are not an acutely relevant research subject for Russian scientists. Thus, there were less than $0.003 / 0.001 \%$ (about 900/300 works out of more than 28 million works) publications on the first/second theme at the end of 2020 in the Russian electronic library E-library (https://elibrary.ru/). 
It is noteworthy that the discussions in this sphere are particularly acute [17, 18] and descriptions of specific experiments and methods rather prevail $[19,20,21]$. As our review of domestic publications has shown, the discussion on energy management issues remains exclusively at the specific level of management $[22,23$, 24], responsible for planning and implementing energy efficiency plans, because both the strategic need and the operational cost of required activities are obvious, and the resource base is always limited. This statement applies equally to corporations in any field of economic activity and to the authorities at the industry, region and municipality level. Discussion is also possible in the field of methods for calculating the efficiency of specific energy management measures at the stage of achievements evaluation [20].

\section{Organizational conclusion}

Introduction of innovations in the energy management system in the region and achievement of energy management goals, including indicators of economic efficiency of the energy sector and energy efficiency of the regional economy in the Leningrad Region as a whole is currently carried out through compliance with the provisions and indicators of a special federal law, the Energy Strategy of Russia (2030), the development strategy of the Leningrad Region for the period up to 2030 and the implementation of the Leningrad Region State Program «Ensuring sustainable functioning and development of communal and engineering infrastructure and energy efficiency in the Leningrad Region» (in 2013).

In our opinion, sluggish implementation of the planned activities in the region is explained by the fact that, despite the certain readiness of the main management actors at the state, municipal and corporate levels to implement some areas, methods and activities of energy management of the world standard, aimed at achieving efficiency indicators set by the planning and legal documents of higher organizations, the executive and consumer levels of activity and consumption are demonstrating a certain lack of understanding of the energy management importance as a strategy and a set of rules conduct in production and everyday life.

In this regard, the regional administration should be concerned about the introduction of elements and even a system of knowledge on personal and industrial energy management into the educational practice (at different levels) $[25,26]$, starting from junior and secondary schools (the individual consumption level), professional schools (the collective and industrial consumption level) and ending with special programs of additional education. This is aimed at the mentality changing of existing managers, public and municipal employees, so that energy management becomes a natural part of management practice, as well as quality management, so that all decisions have been made taking into account the requirements of fundamental documents in this area, not only in Russia, but also at the international level.
The aforesaid allows one to conclude the urgent need for introduction of a more systematic approach to solve the issue of power efficiency at the state and municipal management level of the Leningrad region of the Russian Federation. Namely, increasing power efficiency of the regional social and economic system as the purpose of power management should be considered as a way to improve the system of public production, the environment quality and the life of the population in the region.

\section{References}

1. World Bank Group Report. (2009) Retrieved from: http://www.cenef.ru/file/FINAL_EE_report_rus.pdf

2. I.A. Bashmakov, V.I. Bashmakov, report. Moscow: CENEF (2012) Retrieved from: http://esouz.ru/ENERGOAUDIT/portalenergo_ru_sravnenie_e_ef_v_rossii_i_za_ rubezhom.pdf

3. Energy of the Leningrad Region: vector of development, Const. Techn. Org .J. 03/44,54-57 (2016)

4. Issues of managing the socio-economic development of the Leningrad Region. (St. $\mathrm{Pb}$, PSU, 2018)

5. Strategy of socio-economic development of the Leningrad Region until 2030 (St. Pb, 2017). Retrieved from: http://econ.lenobl.ru/work/planning/concept2030

6. Action Plan for the Implementation of the Strategy of Social and Economic Development of the Leningrad Region until 2030 (St. Pb, 2017) Retrieved from: http://docs.cntd.ru/document/456095537.

7. Forecast of socio-economic development of the Leningrad region for the period up to 2030. (St. $\mathrm{Pb}$, 2015) Retrieved from: http://econ.lenobl.ru/work/social/prognoz/prognoz2 030

8. On energy saving and energy efficiency and on amendments to certain legislative acts of the Russian Federation: Fed.L. 261-FZ (2009)

9. Energy Strategy of Russia 2030, Min. of Ener. of the RF Retrieved from: http:// minenergo.gov.ru/aboutminen/energostrategy/

10. UNIDO Centre for International Industrial Cooperation in the Russian Federation. An. Rep. (2017) Retrieved from:: http://www.unido.ru/upload/files/a/annual_ report_2017_rus.pdf

11. Ensuring sustainable functioning and development of communal and engineering infrastructure and the energy efficiency improvement in the Leningrad region, Resol. of the Gov. of the LR 400 (2013)

12. N.M. Kosmacheva, G.V. Cherkasskaya, Intern. SGEM. 18 (5.3), 343-350 (2018)

13. L.D. Gitelman, B.E. Ratnikov, M.V.Kozhevnikov, Reg. Econ. J. 2(34), 71-84 (2013)

14. Regional report on the state of energy saving and energy efficiency improvements of the Leningrad 
Region at the end of 2019, St. Pub. Ins. of the LR, CESE LR, (2019). Retrieved from: http://www.lenoblces.ru/

15. Rating of administrations of municipal districts (urban district) of the Leningrad region in the field of energy saving and energy efficiency improvements, (2016). Retrieved from: http://www.lenoblces.ru/wpcontent/uploads/2017/01/Rejting-e-nergoeffektivnosti-po-itogam-2016-goda.pdf

16. Rating of administrations of municipal districts (urban district) of the Leningrad region in the field of energy saving and energy efficiency improvements, (2017). Retrieved from:: http://www.lenoblces.ru/wpcontent/uploads/2018/01/Rejting-e-nergoeffektivnosti-po-itogam-2017-goda.pdf

17. E.V. Lyapuntsova, Z.M. Kertbiev, Econ. and Entrep. J. 3(56), 406-410 (2015)

18. A.A. Tupikina, Bus. Educ. Law. J. 2 (31), 219-223 (2015)

19. A.A. Lukinov, I.L.Pichugin, Real Est: Econ. Men. J. 1, 73-77 (2013)

20. I.I. Kashapov, B.G. Ziganshin B.G, Innov. in Agric. J. 2 (23), 19-24 (2013)

21. Yu. E. Polyak, Infor. Resour. of Rus. J. 4 (134), 13-15 (2013)

22. M.N. Dudin, E.E.Frolova, Yu.A.Artemeva, V.V. Bezbakh, A.N. Kirsanov, Intern. J. of Ener. Econ. and Pol. 6. (4), 714-720 (2016)

23. S.M. Voloshin, Innov. in Agric. 2 (12), 9-16 (2015)

24. Z.V. Bragina, E.A. Makhova, Vest. of Kostr. St. Un. named after N.A. Nekras. 17. (5-6), 303-307 (2011)

25. M.S. Dmitrieva, I.V. Bogomolova, Innov. in Inf. Tech., Mech. Eng. and Mot. Trans. ISP Conf. KS TU T.F. Gorbachev,20-22 (2017)

26. G.V. Cherkasskaya, N.M. Kosmacheva, Vocat. Educ. Scien. Innov. in the XXI Cent. ( VIII St. Pb. Congr. NMRMU "Gorny", 84-89 (2014) 